\title{
Median nerve compression by Struthers ligament
}

\author{
LESLIE SURANYI \\ From the Departments of Medicine, Cornwell General and Hôtel Dien Hospitals, Cornwell, Ontario, Canada
}

SUMMARY A 61-year-old patient presented with progressive weakness, pain and numbness in the left arm and hand. On examination the abnormalities were confined to the distribution of the median nerve, and electrophysiological testing localised the lesion to the segment just proximal to the elbow. At surgery Struthers ligament was found compressing the median nerve. No bony spur was found by palpation or on radiological examination.

Median nerve compression at the wrist is a common problem. Entrapment at other locations below or just above the elbow is uncommon. Seven patients with pronator teres syndrome were described by Morris and Peters, ${ }^{1}$ and 39 cases with this condition have recently been reported from the Mayo Clinic. ${ }^{2}$ With few exceptions, median nerve compression proximal to the elbow is discussed in individual case reports. ${ }^{3-6}$ This paper describes the clinical and electrophysiological findings of a case in which compression was caused by Struthers ligament without a supracondylar bony spur.

\section{Case report}

A 61-year-old female was examined on 20 November 1980 because of pain, numbness and weakness in the left arm and hand starting 4-5 weeks previously. On direct questioning, however, she recalled intermittent symptoms months, even years before. The numbness involved the palmar aspect of the left thumb, index, middle and the radial half of the ring fingers. The pain was continuous, localised mostly to the upper medial forearm, always aggravated by repetitive pronation or extension of the arm. The weakness gradually progressed, and the patient found it difficult to make a fist, to squeeze, to hold or lift objects. She was not diabetic and had not suffered any injuries to the left elbow or arm.

On examination there was only questionable decrease in the radial pulse when the arm was fully extended and pronated. No bony spur could be felt by palpation of the right and left humerus. On neurological examination there was

Address for reprint requests: Dr Leslie Suranyi, 238A Augustus Street, Cornwall, Ontario, Canada K6J 3W3.

Received 14 February 1983 and in revised form 10 May 1983. Accepted 14 May 1983 severe wasting and weakness in the forearm flexors and moderate wasting and weakness in the abductor pollicis brevis on the left. Examination of the flexor carpi radialis and especially the pronator teres muscles aggravated the pain. Sensation was decreased in the distribution of the left median nerve, including the base of the thumb. Tinel's sign was present at the elbow, not at the wrist; Phalen's sign was absent. There were no autonomic changes, such as ulcers on the fingertips or decreased sweating.

No bony spur was seen on radiographs of the left humerus. Results of electrophysiological testing done on 4 December 1980 are presented in tables 1 and 2 . They were consistent with localised compression on the median nerve across the elbow segment with signs of segmental demyelination and nerve and muscle fibre loss. Further localisation of the site of compression by the inching technique was not successful. Abnormalities on needle electromyography were consistent with chronic partial denervation in all muscles supplied by the left median nerve and with reinnervation in some of them.

At surgery on 30 January 1981 a band of aponeurotic tissue was found at the usual location of Struthers ligament. When incised, the median nerve was seen underneath, severely stenosed, described by the surgeon as "paper-thin". There was also a conspicuous absence of superficial blood vessels. The segment of the nerve immediately proximal to the ligament was swollen and hyperaemic. No compression of the median nerve could be seen at the two heads of the pronator teres or at the proximal edge of the sublimis muscle. Some subjective improvement was noticed by the patient a few days after surgery. When examined on 20 October 1981 she reported further improvement in muscle power in the left hand and decrease in the pain so disabling prior to surgery. Further improvement became impossible to monitor because the patient developed a disabling lung disease with weight loss and progressive generalised weakness. She suddenly lost her speech and became hemiplegic on 3 January 1983 and died three days later. Permission for necropsy was refused. 
Table 1 Nerve conduction studies

\begin{tabular}{|c|c|c|c|c|c|c|}
\hline Nerve & $\begin{array}{l}\text { Stimulus } \\
\text { site }\end{array}$ & $\begin{array}{l}\text { Recording } \\
\text { site }\end{array}$ & $\begin{array}{l}\text { Latency* } \\
\text { (ms) }\end{array}$ & $\begin{array}{l}\text { Amplitude } \dagger \\
(m V \text { or } \mu V)\end{array}$ & $\begin{array}{l}\text { Distance } \\
(\mathrm{cm})\end{array}$ & $\begin{array}{l}N C V \\
(\mathrm{~m} / \mathrm{s})\end{array}$ \\
\hline Left median $\mathbf{M}$ & $\begin{array}{l}\text { wrist } \\
\text { below elbow } \\
\text { above elbow } \\
\text { axilla }\end{array}$ & $\begin{array}{l}\text { APB } \\
\text { APB } \\
\text { APB } \\
\text { APB }\end{array}$ & $\begin{array}{r}3.3 \\
7.6 \\
10.5 \\
12.7\end{array}$ & $\begin{array}{l}4 \cdot 0 \\
4 \cdot 0 \\
1 \cdot 5 \ddagger \\
1 \cdot 5 \ddagger\end{array}$ & $\begin{array}{r}8 \cdot 0 \\
21 \cdot 2 \\
10 \cdot 0 \\
12 \cdot 4\end{array}$ & $\begin{array}{l}49 \cdot 3 \\
34 \cdot 5 \\
56 \cdot 4\end{array}$ \\
\hline Left ulnar $\mathbf{M}$ & $\begin{array}{l}\text { wrist } \\
\text { above elbow }\end{array}$ & $\begin{array}{l}\text { ADM } \\
\text { ADM }\end{array}$ & $\begin{array}{l}3 \cdot 7 \\
7 \cdot 1\end{array}$ & & $\begin{array}{l}8 \cdot 0 \\
\text { NM }\end{array}$ & - \\
\hline Right median $\mathbf{M}$ & $\begin{array}{l}\text { wrist } \\
\text { below elbow } \\
\text { above elbow } \\
\text { axilla }\end{array}$ & $\begin{array}{l}\text { APB } \\
\text { APB } \\
\text { APB } \\
\text { APB }\end{array}$ & $\begin{array}{r}3 \cdot 4 \\
7 \cdot 3 \\
9 \cdot 1 \\
11 \cdot 1\end{array}$ & $\begin{array}{l}9 \cdot 0 \\
9 \cdot 0 \\
8 \cdot 0 \\
8 \cdot 0\end{array}$ & $\begin{array}{r}8 \cdot 0 \\
21 \cdot 2 \\
10 \cdot 3 \\
12 \cdot 1\end{array}$ & $\begin{array}{l}54 \cdot 4 \\
57 \cdot 2 \\
60 \cdot 5\end{array}$ \\
\hline Left median S & wrist & Index finger & NR & $\overline{10}$ & $\overline{1}$ & - \\
\hline Left ulnar S & wrist & Little finger & $2 \cdot 2$ & 30 & $12 \cdot 0$ & $54 \cdot 5$ \\
\hline Right median S & wrist & Index finger & $2 \cdot 1$ & 40 & $11 \cdot 4$ & $54 \cdot 3$ \\
\hline Right ulnar S & wrist & Little finger & $2 \cdot 2$ & 35 & $12 \cdot 3$ & $55 \cdot 9$ \\
\hline
\end{tabular}

NCV = nerve conduction velocity.

APB $=$ abductor pollicis brevis

$\mathrm{ADM}=$ abductor digiti minimi.

$\mathrm{M} \quad=$ motor.

$\mathrm{S} \quad=$ sensory.

NR $=$ no response.

NM = not measured.

* Measured from stimulus artefact to onset of the initial response for both motor and sensory responses.

†Measured from baseline to negative peak for both motor and sensory responses.

$¥$ The response was prolonged and desynchronised.

Table 2 Needle electromyography

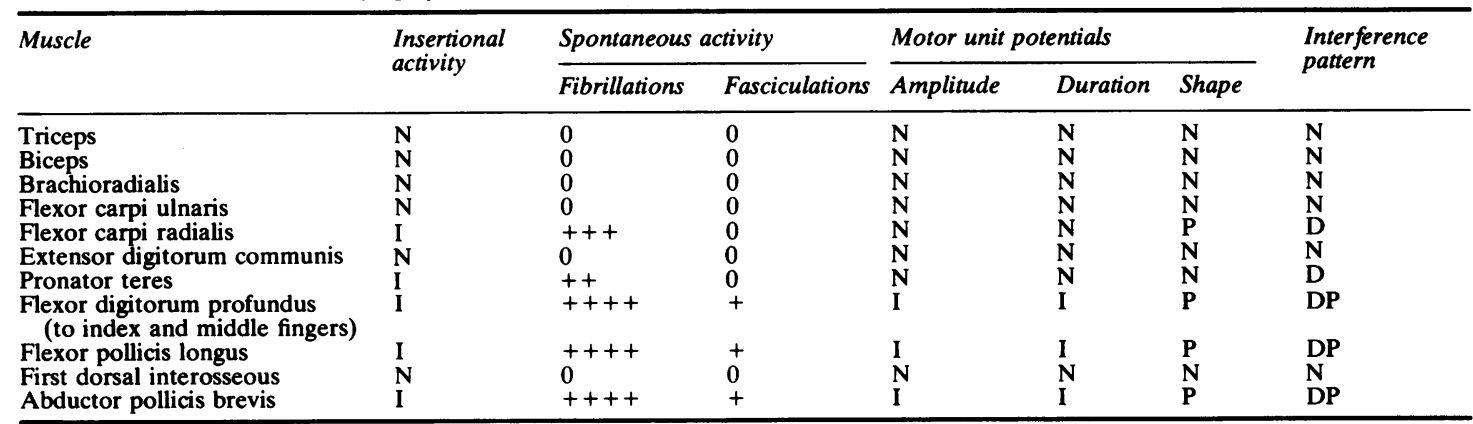

$\mathrm{N}=$ normal.

I $=$ increased.

DP $=$ discrete pattern.

$P=$ increase in polyphasic potentials.

\section{Discussion}

Several unusual aspects of this case made reporting worthwhile. Nearly all previously described patients presented with severe pain at the proximal-medial forearm. Objective neurological abnormalities of this degree are, however, rare. All previously reported cases showed excellent recovery after surgical removal of the spur and/or section of the ligament, in most of them immediately following surgery. There was sone improvement in the present case, but it was slow and mostly subjective. The severe neurological abnormalities and the fact that the nerve was found to be so severely compromised at surgery might explain this. Other clinical features including absence of hypohydrosis in the hand, no significant change in radial pulse upon extension and supination of the forearm, and no nocturnal discomfort are in keeping with other previously described cases. $^{3-7}$ Differentiation between pronator teres syndrome and compression by Struthers ligament is said to be easy because of involvement of the pro- 
nator teres muscle in the latter and not in the former. This may in fact be difficult because of the aggravation of pain in the forearm with the usual testing of power of the prenator teres muscle.

A supracondylar bony spur occurs in $0.7 \%$ to $2.7 \%$ of the population, ${ }^{8}$ usually as an incidental radiological finding. Only a small percentage of people develop symptoms. It is even more uncommon to have compression on the median nerve by Struthers ligament in the absence of a bony spur. We are aware of only one previously reported case, ${ }^{4}$ although Struthers himself found the ligament without a bony component in some of his asymptomatic subjects.9 Absence of a bony spur by palpation or on radiographs certainly does not rule out the possibility of median nerve compression by Struthers ligament.

Only brief references to electrophysiological results can be found in previous descriptions of this condition. Smith and Fisher ${ }^{4}$ and Laha et $a^{5}$ describe mild abnormalities, neither giving details of the results. Electrophysiological studies of pronator teres syndrome are more extensive,$^{12}$ and agree that abnormalities are inconsistent and mild. The study by Buchthal et $a l^{10}$ dealt mostly with median nerve dysfunction at the wrist. In the most recent of these reports only $30 \%$ of forearm conduction values were found to be abnormal. ${ }^{2}$ In the present case the abnormalities were unusually severe, and made reasonably accurate localisation possible.

\section{References}

${ }^{1}$ Morris HH, Peters BH. Pronator syndrome: clinical and electrophysiological features in seven cases. $J$ Neurol Neurosurg Psychiatry 1976;39:461-4.

${ }^{2}$ Hartz CR, Linscheid RL, Gramse RR, Daube JR. The pronator teres syndrome: compressive neuropathy of the median nerve. J Bone Joint Surg (A) $1981 ; 63(6): 885-90$.

${ }^{3}$ Kessel L, Rang M. Supracondylar spur of the humerus. $J$ Bone Joint Surg (B) 1966;48(4):765-9.

${ }^{4}$ Smith RV, Fisher RG. Struthers ligament: a source of median nerve compression above the elbow. $J$ Neurosurg 1973;38:778-9.

${ }^{5}$ Laha RK, Dujovny M, DeCastro SC. Entrapment of median nerve by sypracondylar process of the humerus. J Neurosurg 1977;46:252-5.

${ }^{6}$ Mittal RL, Gupta BR. Median and ulnar nerve palsy: an unusual presentation of the supracondylar process. $J$ Bone Joint Surg (A) 1978;60(4):557-8.

${ }^{7}$ Martinelli P, Gabellini AS, Poppi M, Gallassi R, Pozzati E. Pronator syndrome due to thickened bicipital aponeurosis. J Neurol Neurosurg Psychiatry 1982;45:181-2.

${ }^{8}$ Terry RJ. A study of the supracondyloid process in the living. Am J Phys Anthropol 1921;4:129-39.

${ }^{9}$ Struthers J. On the processus supra-condyloideus humeri of man. Trans Int Med Congr London $1881 ; 1: 148-51$.

${ }^{10}$ Buchthal F, Rosenfalck A, Trojaborg W. Electrophysiological findings in entrapment of the median nerve at wrist and elbow. J Neurol Neurosurg Psychiatry 1974;37:340-60. 